\title{
Results of Analysis of Digital Elevation Models Used Site Selection for Paleoseismological Investigations at the Rurrand Fault
}

\author{
K.G. Hinzen, K. Reamer \& T. Rose
}

Universität zu Köln, Department of Earthquake Geology, Vinzenz-Pallotti-Str. 26, D-51429 Bergisch Gladbach; e-mail: hinzen@uni-koeln.de

Manuscript received: July 2000; accepted: April 2001

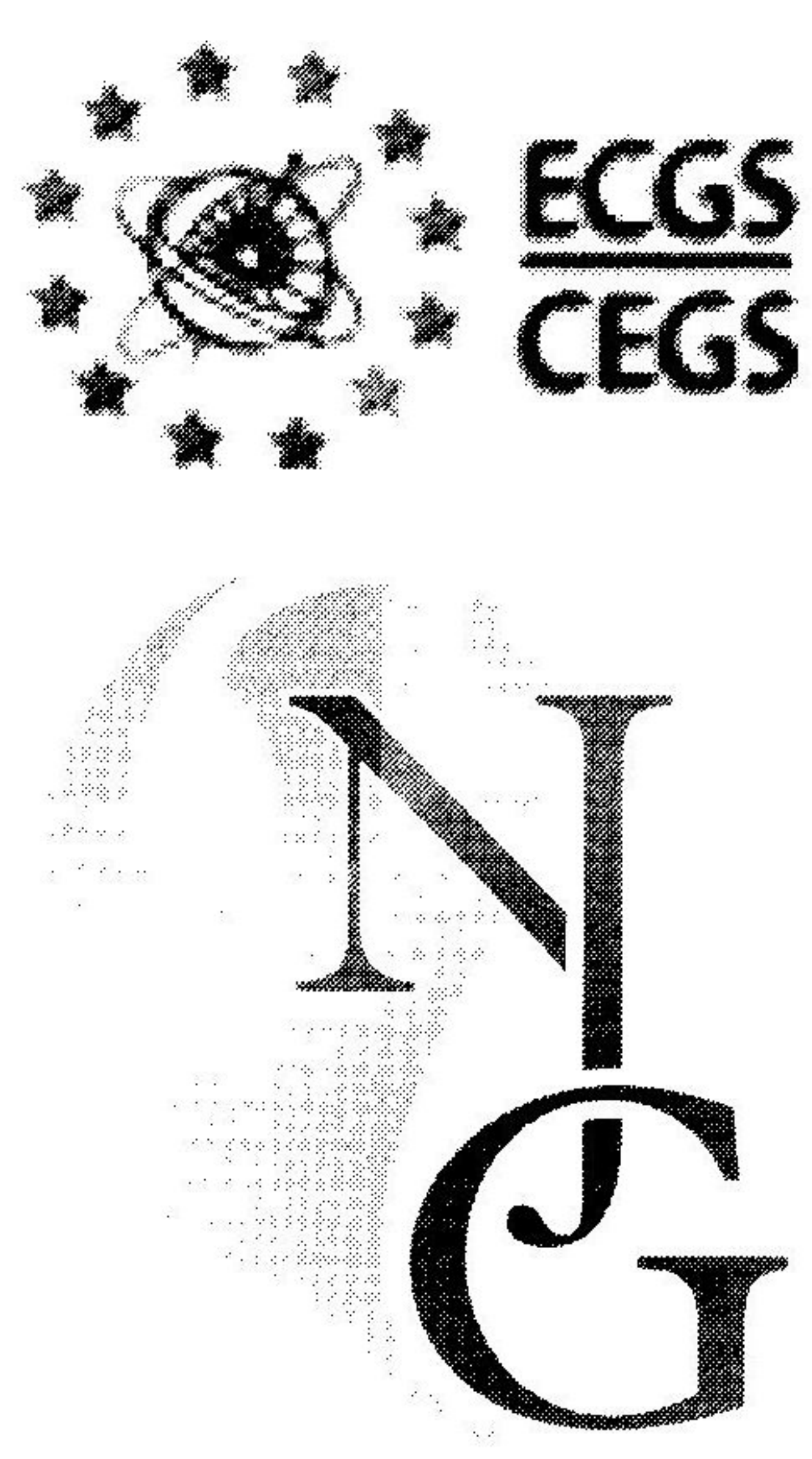

\begin{abstract}
Topographic and morphologic models based on detailed Digital Elevation Models (DEM) of the Rur Graben, in particular a $33 \mathrm{~km}$ section of the Rurrand Fault, proved to be essential in preliminary investigations for the site selection of a trench for detailed paleoseismological investigations. The entire DEM in the $33 \mathrm{~km}$ Jülich-Düren area displayed as a color-shaded terrain map clearly illustrates the main features of the eastern border fault of the Rur Graben. As investigations concentrated on the $8 \times 6 \mathrm{~km}$ Stetternich-Hambach section of the Rurrand fault, the use of contoured topographic, gray-shaded terrain and terrain slope maps helped delineate the main features of the surface fault expression. On the basis of topographic profiles constructed from the DEM, no fault scarp could be identified; however, the detailed surveying results from two geophysical profiles correlated well with the topographic data.
\end{abstract}

Keywords: Lower Rhine Embayment, paleoseismology, digital elevation model, shaded terrain map, Rur Graben, earthquakes

\section{Introduction}

The Lower Rhine Embayment (LRE) with the Rur Graben as a main tectonic feature is part of the European rift system that developed in the middle to late Eocene. The rift system includes the Upper Rhine Graben and the Middle Rhine Zone (Meyer, 1988, Ziegler, 1994, Ziegler, 1982, Geluk et al., 1994). The Upper Rhine Graben, the Hessian Graben and the Lower Rhine Graben form a triple junction in the Frankfurt/Main area (Fig. 1). The Hessian Graben shows little evidence of neotectonic activity at present (deCrook, 1993). During the past 30 million years, the crust in the LRE subsided and broke into several blocks. Northwest-southeast striking normal faults border the LRE to the west. Current slip rates on these faults are estimated to be on the order of 0.1 $\mathrm{mm} /$ year. The active seismic zone along the Rhine river, including the Upper Rhine Graben, the Middle
Rhine Area, the Lower Rhine Valley, and extending to the Belgian earthquake zone, is the most important earthquake zone of Middle Europe north of the Alps. The Lower Rhine Embayment with the Rur Graben exhibits low to moderate seismicity, typical for an intraplate earthquake zone. Epicenters are concentrated in the western half of the system and can be correlated with the main border faults of the graben system.

Recent paleoseismological investigations (Camelbeeck and Meghraoui, 1996 and 1998) in the Rur Graben proved the occurrence of surface rupturing earthquakes throughout the last 10,000 years in this zone of present-day low seismic activity. The potential for reoccurrence of such large earthquakes in the densely populated and highly industrialized area of the Lower Rhine Embayment and its vicinity is a major concern. To improve the overall picture of seismic activity in areas of present-day low seismic activity in Europe, paleoseismological investigations were made 


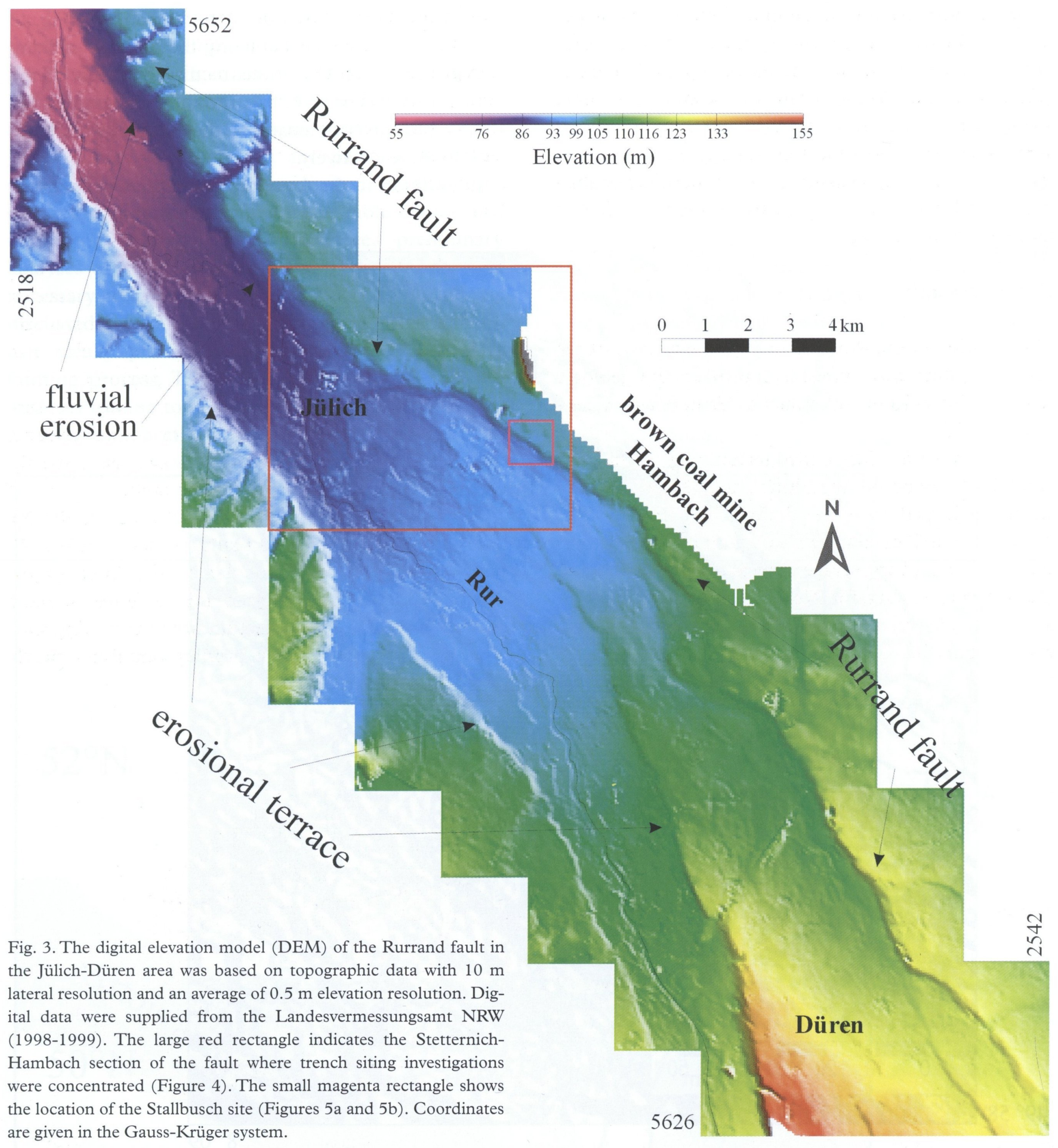

geological and tectonic maps from the Geological Survey of North-Rhine-Westphalia (NRW) were used to identify and select potential trench sites. The process of trench selection entailed the solution of some potential problems, as the area in question is intensively populated and highly industrialized. Therefore, traffic, power and gas lines prevent trenching operations in some locations on the German side of the Lower Rhine Graben. In addition, the entire target area has been affected by large-scale groundwater extraction associated with past and ongoing brown coal mining activities from the Rheinbraun AG mining

company. The extraction of brown coal and groundwater results in manmade subsidence. This subsidence is especially prevalent along the existing natural faults. Therefore, the Rheinbraun AG mining company cooperated with the investigators during the site selection process to identify sites where the subsidence effects were known. An important requirement was that the water table at the trench site should lie below $5 \mathrm{~m}$ depth to obviate the necessity for water extraction during the trench opening phase. The extra costs associated with continuous water removal would have made the trench opening intractable. 
Based on these and additional factors such as the horizontal extent of straight segments along the fault and inferred vertical movements during the Holocene (Geluck et al., 1994; Camelbeeck and Van Eck, 1994), the Viersener Fault and the Rurrand Fault were selected as possible trenching sites. After comparison of existing measurements of manmade subsidence and water table levels, the Rurrand fault was targeted for trenching.

\section{Rurrand Fault}

The location of the Rurrand fault in the vicinity of the cities of Jülich and Düren is shown on the geologic map of North-Rhine-Westphalia (Prüfert and Thiermann, 1990).

Fig. 3 shows a color-shaded terrain map of the Rurrand fault section between Jülich and Düren enlarged from the jagged blue area indicated in Fig. 2. This model is based on elevation data with a lateral resolution of $10 \mathrm{~m}$ and an average vertical resolution of $0.5 \mathrm{~m}$ (Landesvermessungamt Nordrhein-Westfalen, 199899). The data were digitized from 1:5000 topographic maps from the Landesvermessungsamt Nordrhein-
Westfalen. Each single map comprises a square area of $2 \mathrm{~km} \times 2 \mathrm{~km}$ and occupies approximately $1 \mathrm{Mb}$ of storage space on a PC. More than 50 maps were combined in the DEM of the Rurrand fault (Fig. 3). Elevations range from $50 \mathrm{~m}$ to $155 \mathrm{~m}$. A standard kriging algorithm with linear variogram was used for datapoint interpolation (Cressie, 1991). The Rurrand fault is expressed as the northernmost topographic step (east of Jülich and Düren) visible striking NW$\mathrm{SE}$ in the DEM in Fig. 3. Additionally, parallel to and west of the strike of the fault, the erosional terrace of the Rur river can be seen in Fig. 3. The average slope along the Rur river within the map area of Fig. 3 is $0.14^{\circ}$ as measured from the topographic map (1:5000). North of the city of Jülich, the Rur river terrace abuts the topographic expression of the Rurrand faults. Indeed, the Rur river drainage has partially eroded the surface expression of the fault.

A total of 200 topographic profiles across the 33 $\mathrm{km}$ section of the Rurrand Fault (as shown in Fig. 3) was constructed perpendicular to the fault strike. These profiles were analyzed for evidence of fault scarp and to aid in the selection of the trenching site. The steepest slopes in these profiles were found north

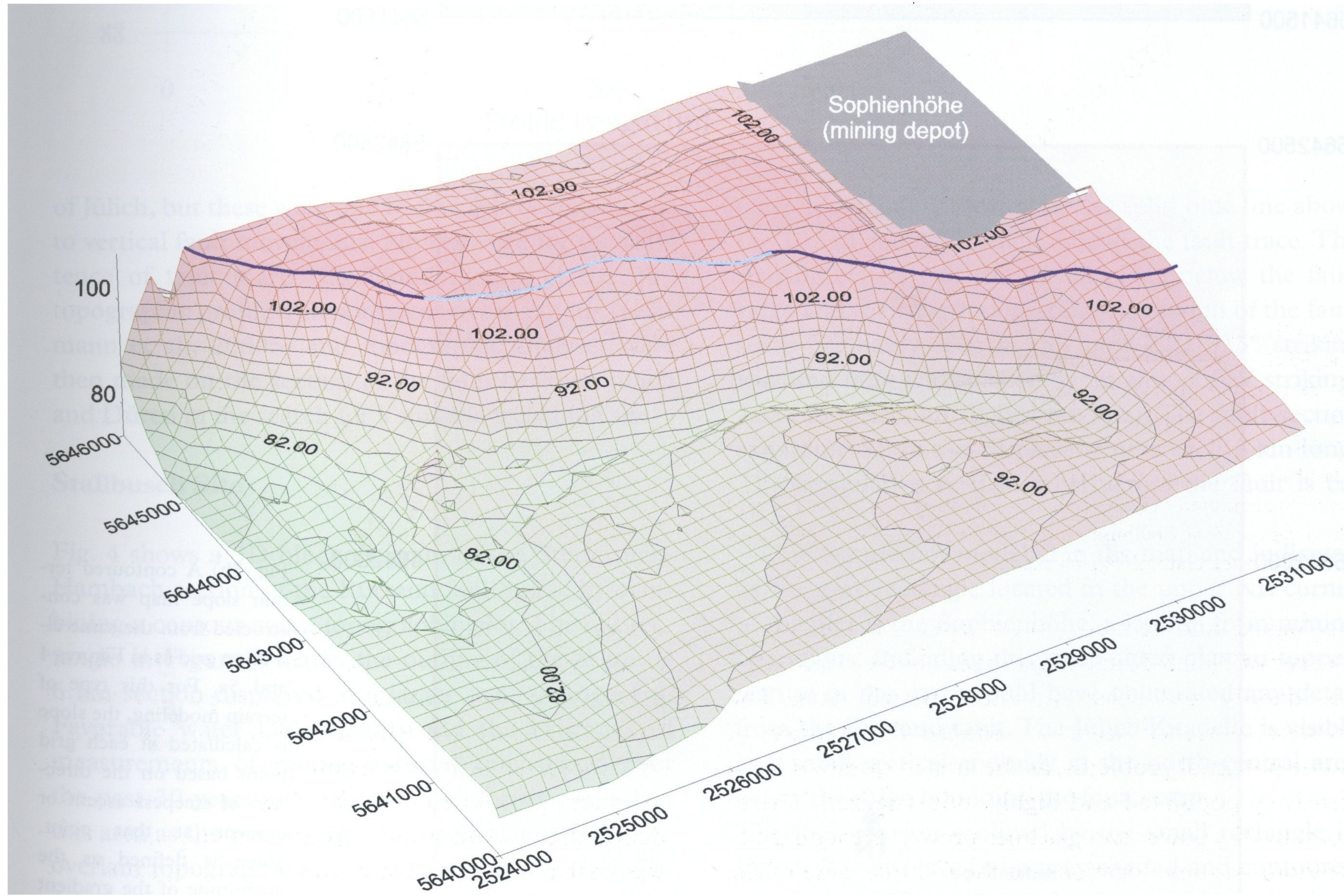

Fig. 4. The contoured 3D topographic map of the Stetternich-Hambach section of the Rurrand fault shows the approximate strike of the Rurrand fault in dark blue. A 2-km-long E-W striking segment is indicated in light blue. Red grid mesh lines indicate elevations between 90$105 \mathrm{~m}$. Green mesh lines extend from 70-90 m. The Sophienhöhe, a mining landfill with steeply ascending sides was excluded from the topographic modeling. Coordinates are in the Gauss-Krüger system. 


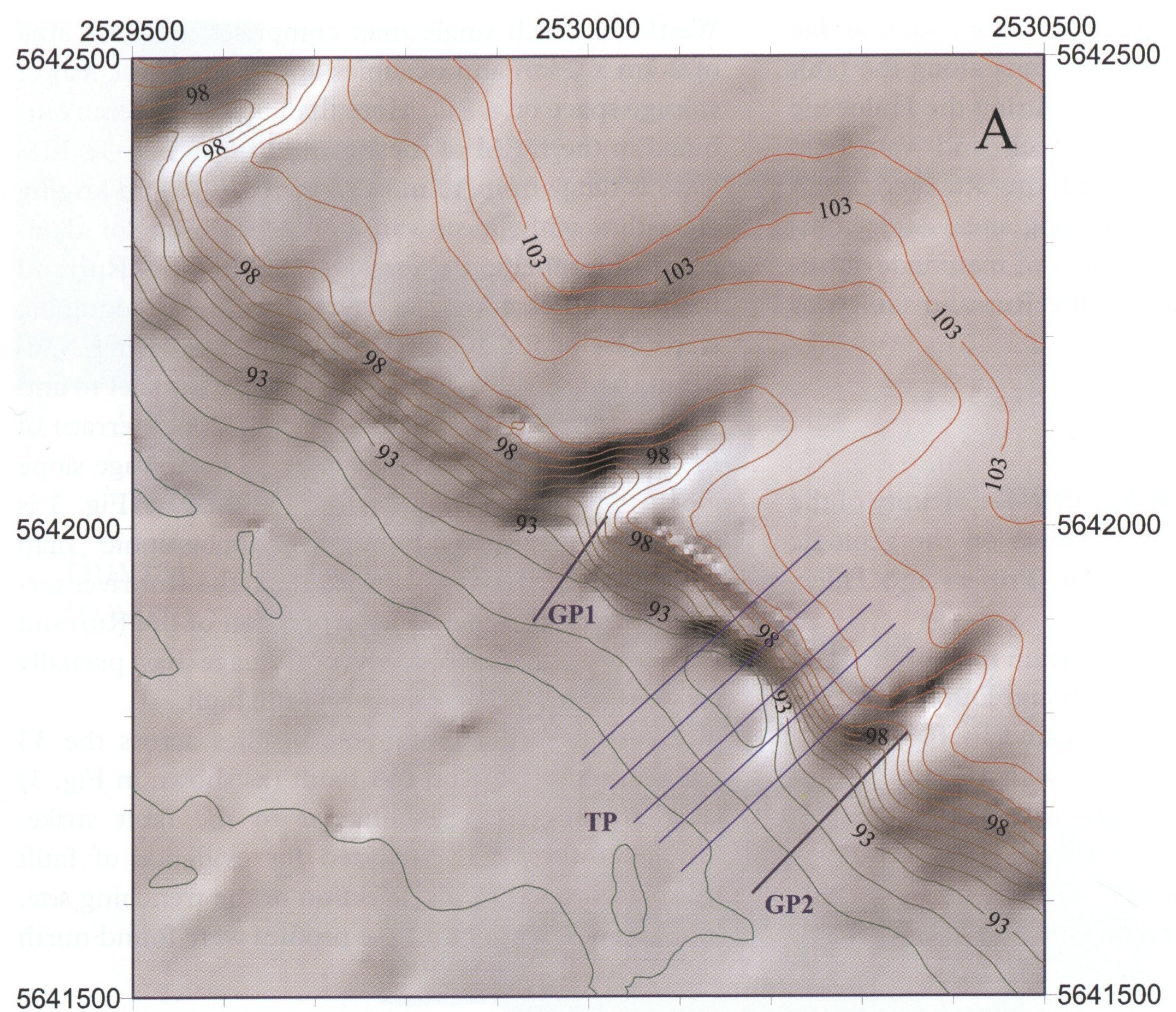

Fig. 5a) A gray-shaded terrain map of the Stetternich-Hambach section of the Rurrand fault shows the location of selected trenching site at Stallbusch (GP1). The dark blue lines are the profiles along which geophysical explorations (seismic, geoelectric and ground penetrating radar) were made. The bright blue lines indicate where topographic profiles were constructed.

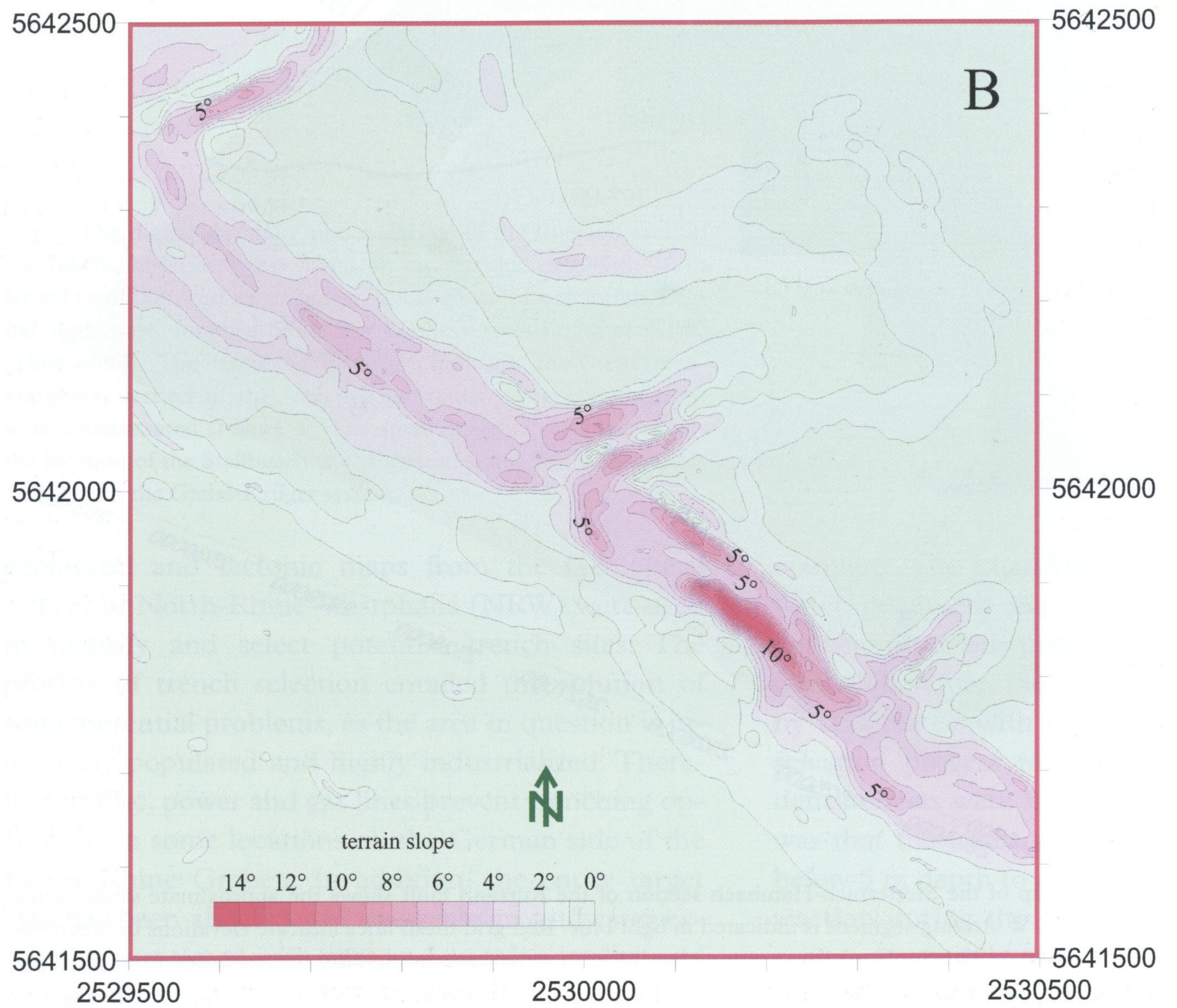

Fig. 5b) A contoured terrain slope map was constructed from the same elevation grid as in Figures 4 and 5a. For this type of terrain modeling, the slope is calculated at each grid point based on the direction of steepest ascent or descent at that point. Slope is defined as the magnitude of the gradient at that point. The steepest slope is found southeast from the trench site (GP1). 


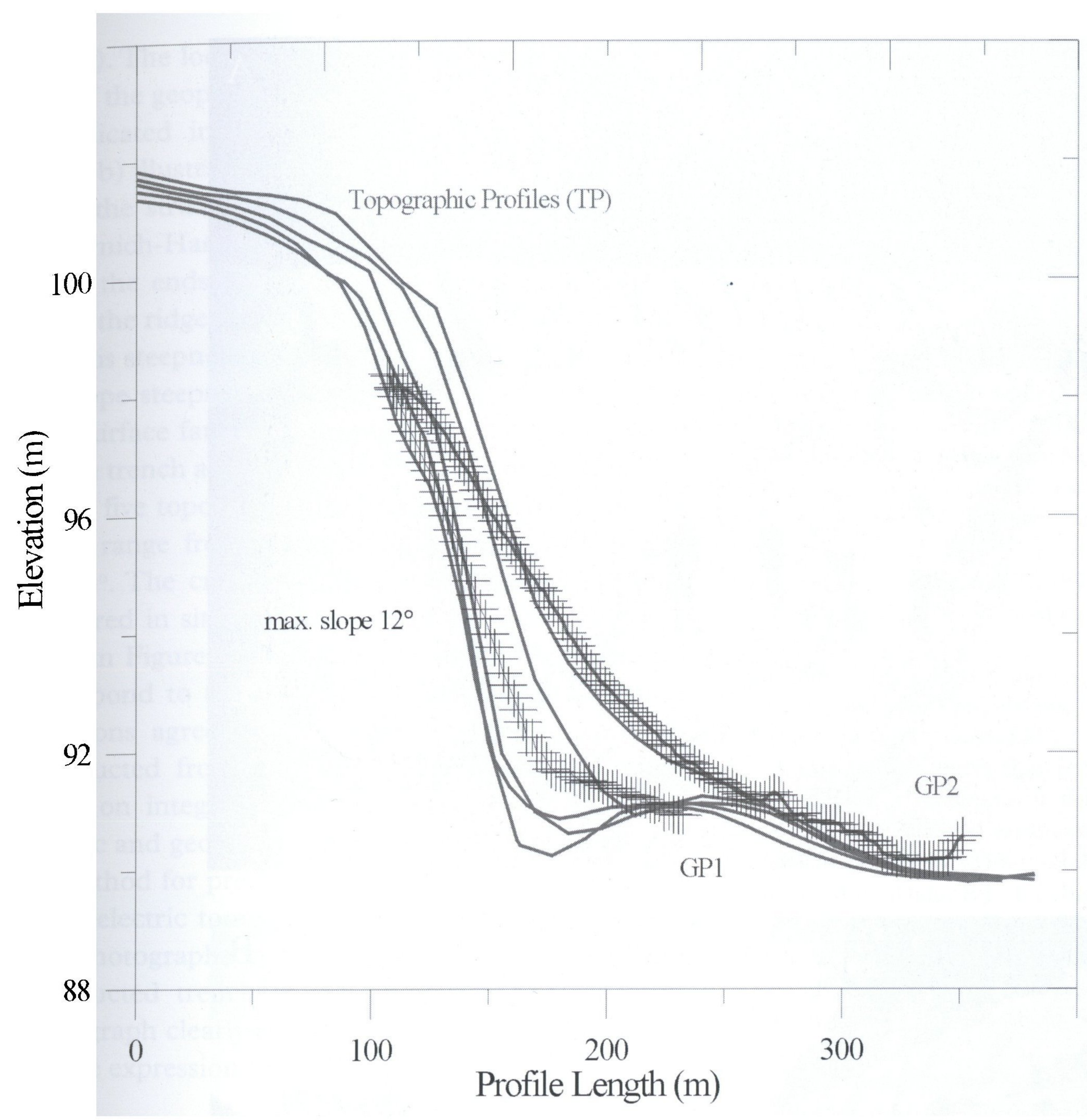

Fig. 6. Five elevation profiles were constructed across the Rurrand Fault in the vicinity of the Stallbusch trenching site (GP1). The vertical scale is exaggerated by a factor of 25 . The bright blue lines are profiles constructed from the DEM (Figure 2). Dark blue crosses indicate elevations measured in situ along the geophysical profile lines (GP1 and GP2) shown in Figure 5a.

of Jülich, but these were due to fluvial erosion and not to vertical fault movements. No evidence for the existence of fault scarp was found in any of the 200 topographic profiles. Geophysical investigations (Lehmann et al., 2000b) and topographic analyses were then made on the section of the fault between Jülich and Düren in the search for a suitable trenching site.

\section{Stallbusch Site}

Fig. 4 shows a 3D block diagram of the StetternichHambach section of the Rurrand fault made by combining a contour and a topographic plot. The red rectangle in Figure 3 marks the outline of the $8 \mathrm{~km}$ by $6 \mathrm{~km}$ section displayed at a larger scale in Figure 4. Favorable water table depths and the existence of measurements of mining-induced movements over the past 30 years factored into the decision to select this area as the prime target for opening a trench. The overlain topographic map elevations extend from 70$105 \mathrm{~m}$. Lower elevations $(70-90 \mathrm{~m})$ are indicated by the green-colored mesh lines, and higher elevations between $90-105 \mathrm{~m}$ are delineated by the red-colored mesh lines. The topographic expression of the fault scarp is roughly indicated by the solid blue line above the $102 \mathrm{~m}$ contour, which follows the fault trace. The striking contrast of the fluvial plane below the fault ridge and the clear topographic expression of the fault scarp are easily seen in this plot. The $315^{\circ}$ striking Rurrand fault is displaced by an almost EW striking, $2 \mathrm{~km}$ long section (light blue line). The fault section extending SE of this displacement is ca. $7.5 \mathrm{~km}$ long. The cumulative vertical relief across the fault is ca. $10 \mathrm{~m}$.

One feature not modeled in the map and indicated by the gray rectangle located in the upper NE corner of the plot is the Sophienhöhe, a landfill from mining operations. Including this steep-sided plateau-topped feature in the map would have obliterated any detail from the Rurrand fault. The Jülich Zitadelle is visible as a small vertical anomaly in the north-central area below the ridge bounding the fault scarp.

The fault section outlined by the small rectangle in Figure 3 is displayed as a gray-shaded and contoured terrain map (Figure 5a) and a contoured terrain slope map (Figure 5b) delineates the erosional surfaces cut by streams draining toward the Rur river.

The morphological expression of a fault scarp was 

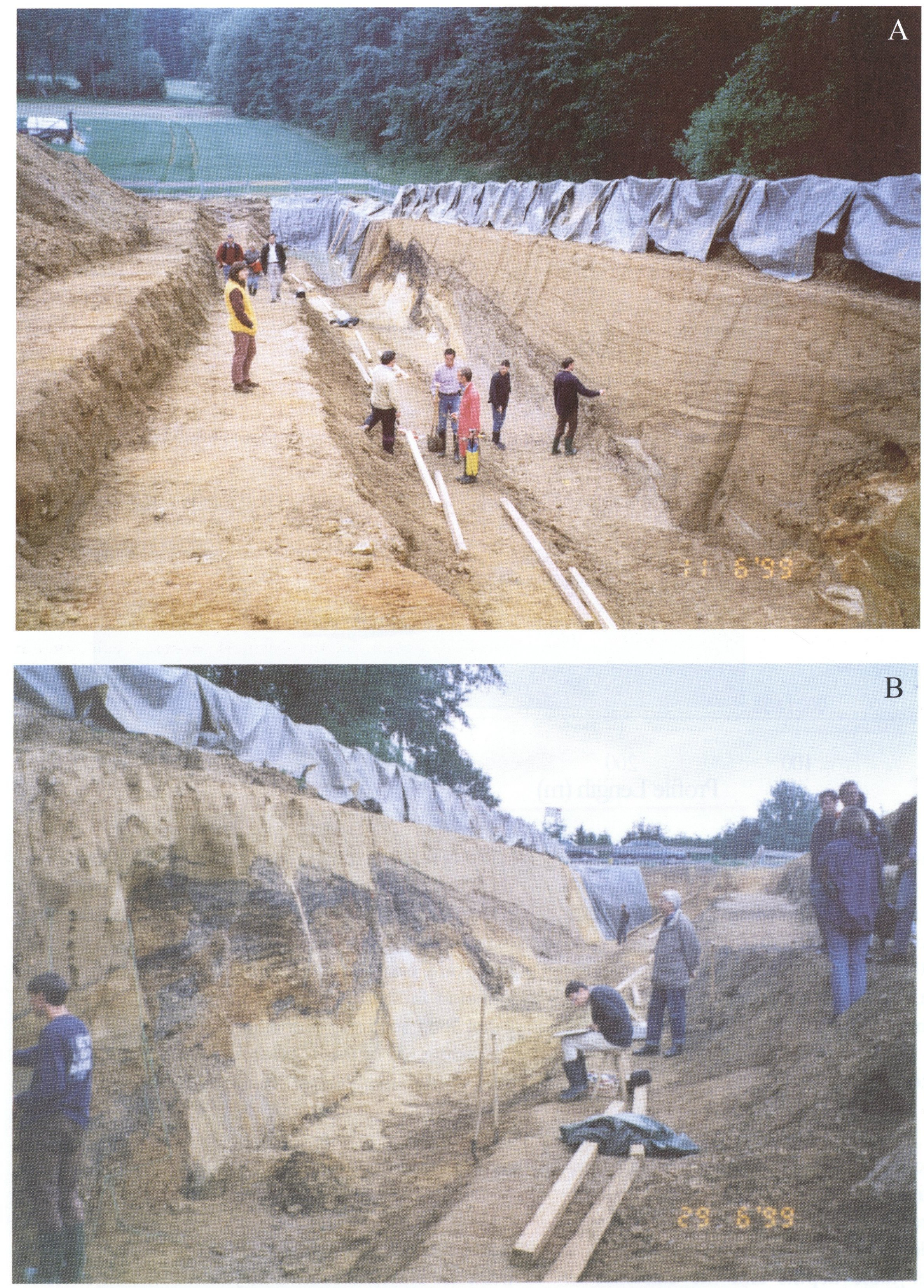

Fig. 7. The two photographs show the ongoing paleoseismological investigations at the Stallbusch site after opening of the trench. The top photograph shows a view from east to west looking downslope on the Rurrand fault. The bottom photograph was taken from within the trench with an upslope view of the Rurrand fault from west to east.

not evident in any of the constructed topographic profiles. In Figure 5a, the location of five topographic profiles (TP) and two geophysical profiles (GP1 and GP2) across the fault scarp are indicated by the dark blue and bright blue lines, respectively. Geophysical measurements included geoelectric sounding, geoelectric tomography, ground penetrating radar and high-resolution reflection seismic (Lehmann et al., 
2000 b). The location of the trench is congruent with that of the geophysical profile (GP1) to the northwest as indicated in Figure 5a. The terrain slope map (Fig. 5b) illustrates well the gradient of the fault ridge along the strike of the fault. The slope varies across Stetternich-Hambach section from less than $5^{\circ}$ towards the ends to as steep as $14^{\circ}$ to the southwest, where the ridge is curved slightly inward. We presume that this steepness resulted from fluvial erosion. Since the slope steepness were attributed to erosion rather than surface fault expression, it was not necessary to dig the trench across the steepest slope of the ridge.

The five topographic profiles constructed from the DEM range from a maximum slope of $12^{\circ}$ to less than $4^{\circ}$. The crosses in Figure 6 indicate elevations measured in situ along the geophysical profiles indicated in Figure 5a at the Stallbusch site. The crosses correspond to the trench site (GP1). The measured elevations agree well with the topographic profiles constructed from the DEM. The trench was sited based on integration of the results from the topographic and geophysical investigations. The most useful method for precise location of the fault proved to be geoelectric tomography (Lehmann et al., 2000b). The photographs in Figure 7 show two views of the constructed trench at the Stallbusch site. The top photograph clearly shows the terrain slope due to the surface expression of the Rurrand fault.

\section{Conclusions}

The use of DEMs and topographic analysis of fault expression for the location of potential trenching sites for paleoseismological investigations can be a useful tool where overriding logistical factors such as industrialization and population density severely limit the location of a trenching site. However, within these constraints, the use of detailed digital topographic data, map and profile construction integrated with geophysical analysis (Lehmann et al., 2000b) provided a useful method for optimizing the site selection process along the eastern border faults of the Rur Graben.

\section{Acknowledgements}

This work was done in the framework of the EU Project ENV4-CT97-0578 EC in the Program Environment and Climate. We thank Rheinbraun AG for the help in the site selection process. Digital elevation data were supplied by the Landesvermessungsamt NRW (S 975/98). We thank S. Pietsch and V. Bolz for their help in preparing the data and R. Pelzing for numerous helpful discussions. N. D'Agostino and F.
Doumaz helped to improve the manuscript with their comments.

\section{References}

Brondeel M., Meghraoui, M. \& Camelbeek, T., 1997. Detailed geomorphic analysis of the Bree active fault scarp. Ardk. Mededel., $84^{\text {th }}$ Journées Luxembourgeoises de Géodynamique (Munsbach/Luxembourg).

Camelbeek T. \& Meghraoui, M., 1996. Large earthquakes in Northern Europe more likely than once thought. Eos, Transactions, American Geophysical Union 77, No 42: 405-409.

Camelbeeck, T. \& Meghraoui, M., 1998. Geological and geophysical evidence for large paleoearthquakes with surface faulting in the Roeir Graben. Geophysical Journal International 132: 347362.

Camelbeek T. \& Van Eck T., 1994. The Roer Valley graben earthquake of 13 April 1992 and its seismotectonic setting, Terra Nova, 6: 291.

Cressie, N.A.C., 1991 Statistics for spatial data. John Wiley and Sons, Inc., New York, 900 pp.

Davenport, C.A., Lap, J.M.J., Maurenbrecher, P.M \& Proce, D.G., 1994. Liquefaction potential and dewatering injection structures at Herkenbosch: field investigations of the effects of the 1992 Roermond earthquake, the Netherlands. Geologie en Mijnbouw 73: 365-374.

Geluk, M.C., Duin, E.J.Th, Dusar, M., Rijkers, R.H.B., van den Berg, M.W. \& van Roijen, P., 1994. Stratigraphy and tectonics of the Roer Valley Graben. Geologie an Mijnbouw 73: 129-141.

Landesvermessungsamt Nordrhein-Westfalen, 1972. Deutsche Grundkarte 1:5000, sections Stetternich, Neulich, Daubenrath, Hambach, (Bonn).

Landesvermessungsamt Nordrhein-Westfalen, 1998-1999. Digital elevation model of North Rhine Westphalia DGM 5, various sections, (Bonn).

Lehmann, K., Pelzing, R. \& Klostermann, J., 2000a. Paleoseismological Investigations at the Rurrand Fault, Lower Rhine Embayment. Geologie en Mijnbouw, 80, 139-154.

Lehmann, K., Klostermann, J., Pelzing, R., \& Hinzen, K.-G.., 2000b. Paleoseismological investigations at the Rurrand fault, FRG. Proceedings Workshop, HAN2000, Han-su-Lesse: 93-96.

McCalpin, P., 1996. Paleoseismology. Academic Press (London): $583 \mathrm{pp}$.

Nieuwenhuis, J.D., 1994. Liquefaction and the 1992 Roermond earthquake, the Netherlands. Geologie en Mijnbouw 73: 357364.

NOAA, 1999. Global Relief CD-Rom. United States Department of Commerce (Washington, D.C.)

Prüfert, J. and Thiermann, R., 1990. Geologische Karte von Nordrhein-Westfalen 1:100,000: Landesamt, Nordrhein Westfalen (Krefeld, Germany).

U.S. Geological Survey, 1993. Digital elevation models, data user guide 5 (Reston, Virginia): 50 pp.

Ziegler, P.A., 1982. Geological atlas of Western and Central Europe. Elsevier Science Publishers (Amsterdam): 155 pp. 